Marcin Niemojewski

Uniwersytet Warszawski

pasaka@poczta.onet.pl

\title{
Donelaitis i Baranauskas: między piśmiennością a literaturą
}

Słowa kluczowe: oralność, piśmienność, literatura, historia kultury, tożsamość narodowa

Keywords: orality, literacy, literature, history of culture, national identity

Twórczość literacką Kristijonasa Donelaitisa, luterańskiego pastora $\mathrm{w}$ Tolminkiemis ${ }^{1}$ i Antanasa Baranauskasa, duchownego katolickiego, pod koniec życia biskupa sejneńskiego, mimo że reprezentowali różne epoki w dziejach piśmiennictwa litewskiego, łączy wiele podobieństw. Należy zacząć od tego, że dorobek obu duchownych w dziedzinie sztuki słowa był dosyć skromny, obaj bowiem nad aspiracje pisarskie przedkładali obowiązki kapłańskie. Znana spuścizna rękopiśmienna Donelaitisa obejmuje sześć bajek w duchu Ezopa $^{2}$, cztery obszerne pieśni składające się na poemat Metai (Pory roku), fragmenty czy też szkice tych pieśni, trzy wiersze w języku

\footnotetext{
${ }^{1}$ Tolminkiemis ma swoją polską nazwę: Tolminkiejmy lub Tołminkiejmy, jednak ze względu na jej bardzo ograniczone zastosowanie we współczesnej polszczyźnie (brak nawet rozstrzygnięcia co do formy zapisu) pozostaję przy nazwie w jej litewskim brzmieniu. Miejscowość ta leży obecnie w Obwodzie Kaliningradzkim i nosi nazwę Czystyje Prudy.

${ }^{2}$ Taką interpretację narzucił już ich pierwszy wydawca, zob.: L. Rėza (na stronie tytułowej: D.L.J. Rhesa), Aisopas arba Pasakos isz Grykonu kalbos pergulditos per D.L.J. Rhesa, supridejimu kellu nauju pasaku, Karalauczus (Królewiec) 1824. Bajki Donelaitisa stanowią tu tylko dodatek, obejmujący końcową część publikacji (od s. 60, błędnie oznaczonej w edycji jako 61). W dalszej części tekstu, podobnie jak w tym przypisie, używam nazwiska Rèza zgodnie z pisownią przyjętą we współczesnej litewskiej literaturze przedmiotu.
} 
niemieckim, listy, broszurę o tematyce społecznej, zapisy w księgach metrykalnych oraz niewielki zbiór pism i dokumentów parafialnych, głównie po niemiecku³ ${ }^{3}$ Utwory literackie nie były ogłoszone drukiem za życia autora, niewykluczone też, że część z nich zaginęła ${ }^{4}$. Po Antanasie Baranauskasie mamy spuściznę obfitszą i bardziej zróżnicowaną. Miejsce najbardziej znaczące zajmuje w nim ponownie poemat, Anykščiu šilelis (Borek oniksztyński), utwór romantyczny napisany w latach 1858-1859. Obok niego dorobek literacki współtworzą poezje z młodzieńczego okresu, spisane w języku polskim ${ }^{5}$, dojrzalsze wiersze, które powstawały już po litewsku oraz pieśni religijne, a autorka biografii i redaktorka edycji jego prac Regina Mikšytė włącza do niego także listy i pisany w młodości dziennik osobisty. Warto jednak już w tym miejscu podkreślić, że Baranauskas próbował swoich sił także na polu językoznawczym, co dokumentują studia i artykuły z tej dziedziny, począwszy od polskiej rozprawki O mowie ludu żmudzkiego i litewskiego ${ }^{6}$, interesował się również żywo matematyką i naukami przyrodniczymi, czemu dawał wyraz w publikacjach po polsku, rosyjsku i niemiecku na łamach czasopism

\footnotetext{
${ }^{3}$ Cały znany dorobek poety wydany został w jednym tomie: K. Donelaitis, Raštai, red. K. Korsakas, Vilnius 1977.

${ }^{4}$ Niektóre teksty Donelaitisa zostały odnalezione, zidentyfikowane i krytycznie opracowane dopiero w XX wieku. Pierwszej próby systematycznego i pełnego uporządkowania tej spuścizny i nowych znalezisk podjął się Vaclovas Biržiška w trzytomowym dziele Aleksandrynas, wydanym po raz pierwszy na emigracji, w Chicago w połowie lat 60 . XX stulecia. Praca ta doczekała się również wydania w niepodległym państwie litewskim: V. Biržiška, Aleksandrynas. Senuju lietuviu rašytojų, rašiusiu prieš 1865 m., biografijos, bibliografijos ir biobibliografijos, T. I-III, Vilnius 1990. Hasło poświęcone Donelatisowi w tymże wydaniu: T. II, s. 73-92.
}

${ }^{5}$ Opis początków twórczości znaleźć można w jedynym poświęconym biskupowi sejneńskiemu jako twórcy literatury litewskiej dziele dostępnym w języku polskim: E. Aleksandravičius, Antanas Baranauskas. Szlak wieszcza, przeł. J. Rogoża, T. Błaszczak, Sejny 2014, zwłaszcza w rozdziałach Od pastucha do kancelisty i Lira i krzyż.

${ }^{6}$ A. Baranauskas, O mowie ludu żmudzkiego i litewskiego, [w:] „Litwa” 1112/1913, s.109-112. 
naukowych ${ }^{7}$. Rzecz jasna, osobną część tego archiwum stanowią dokumenty i teksty o tematyce religijnej. $Z$ czasem prace o ambicjach naukowych i dokumenty kościelne zdominowały jego piśmiennictwo - na uprawianie poezji nie znajdował już czasu ani ochoty ${ }^{8}$. Niemniej słowo pisane pozostało dla Baranauskasa jedną z istotnych form uczestnictwa w posłudze duszpasterskiej i życiu kulturalnym.

To przede wszystkim z powodu przywołanych wyżej poematów obaj kapłani-poeci zaliczeni zostali w poczet klasyków literatury litewskiej. Rangę utworu Donelaitisa docenił już jego pierwszy redaktor i wydawca, Liudvikas Rèza, pisząc: Literatura litewska wciąż nie ma ani jednego takiego dzieła narodowego, które moglibyśmy uznać za trwaty, ponadczasowy pomnik języka, obyczajów, kultury duchowej i bytu tego nadniemeńskiego ludu. Dlatego też ośmielam się ofiarować tutaj szerszej publiczności tę prace - dzieło nieznanego jeszcze $w$ świecie literackim autora, Donelaitisa ${ }^{9}$. Twórca Pór roku znalazł uznanie również w oczach tych, dla których język litewski nie był źródłem tożsamości, ale nośnikiem cennej z naukowego punktu widzenia tradycji sąsiedniego narodu. Oskar Kolberg odnotował: Można powiedzieć, że do połowy prawie zeszłego wieku Litwa-oprócz pieśni i legend żyjacych $w$ ustach ludu - nie miała innej literatury nad ksiązi do nabożeństwa. Dopiero w XVIII wieku zjawit się w Litwie pruskiej wieszcz narodowy, Christian Donaleitis [Kolberg zapisał nazwisko zgodnie z jego brzmieniem w pierwszej edycji poematu

\footnotetext{
${ }^{7}$ Zob.: Antanas Baranauskas (1835-1902), [w:] Lietuvių rašytojai. Biobibliografinis žodynas, T.I, red. K. Korsakas, Vilnius 1979, s. 141-152 oraz Antanas Baranauskas, [w:] V. Biržiška, Aleksandrynas. Senujų lietuvių rašytojų, rašiusiu prieš 1865 m., biografijos, bibliografijos ir biobibliografijos, T.III, Vilnius 1990, s. 381-394.

${ }^{8}$ Szerzej o tym: E. Aleksandravičius, Antanas Baranauskas. Szlak wieszcza, op.cit., s. 89 i następne.

${ }^{9}$ L. Rèza (na stronie tytułowej: D.L.J. Rhesa), Vorbericht, [w:] Das Jahr in vier Gesängen : ein ländliches Epos, Konigsberg 1818, s. I (jeśli nie podano inaczej, wszystkie fragmenty z języka litewskiego oraz innych języków obcych w przekładzie autora artykułu).
} 
- przyp. M. N.. ${ }^{10}$. Większa część jego poezji niewydanych zaginęta; najznakomitsza z nich, poemat ,Cztery pory roku”, wydat w r. 1818 w Królewcu znany badacz dziejów i starożytności Litwy i Prus dr Rhesa z przekładem niemieckim. Poemat ten przełożyt i zamierzył wydać wraz z tekstem znawca i miłośnik mowy litewskiej p. M. Akielewicz ${ }^{11}$.

Donelaitis wyróżniany był więc przede wszystkim - niezależnie od różnie interpretowanej wartości artystycznej jego dzieła - jako „prekursor litewskiej literatury pięknej”12, pierwszy twórca oryginalnej poezji świeckiej w tym języku. O pozycji Baranauskasa, choć jemu też przyznano pierwszeństwo w ramach kierunku literackiego, decydowały w pierwszym rzędzie walory poetyckie jego poematu oraz fakt, że dzieło to okazało się istotną inspiracją dla młodszych roczników propagatorów litewskiego słowa drukowanego i adeptów literatury. Znaczenie twórczości Baranauskasa i jej miejsce w piśmiennictwie litewskim XIX wieku tak podsumowuje Regina Mikšytė: Dla dziejów literatury litewskiej Antanas Baranauskas jest ważny jako autor klasycznego utworu Anykščiušilelis - pierwszego poematu romantycznego oraz kilku znaczacych tekstów programowych, dla poezji litewskiej-jako autor najwyższej rangi między Donelaitisem

\footnotetext{
${ }^{10}$ Warto przypomnieć, że nazwiska XIX-wiecznych twórców litewskich, ze względu na wielojęzyczność obszaru byłego Wielkiego Księstwa Litewskiego i Litwy Pruskiej, brak uregulowań dotyczących pisowni litewskiej oraz wielojęzyczność i uwarunkowania społeczno-polityczne samych pisarzy, znamy w wielu wariantach. W rezultacie wersje nazwisk zgodne ze współczesną normą językową litewszczyzny, których używam w niniejszej pracy, pojawiają się w dokumentach z epoki rzadko, obocznie lub w ogóle nie występują. Dla przykładu, Biržiška podaje takie oto, występujące w drukach wersje nazwiska Donelaitisa: Donalitius (forma zlatynizowana, której używał sam duchowny-poeta), Donalizius lub Donalicius, jak zapisywali jego nazwisko pierwsi wydawcy i badacze, Duonelaitis, którą to formę, zawierającą przesłanie symboliczne (duona - chleb), spopularyzowano na początku XX stulecia, wreszcie stosowany przez Rėzę zapis Donaleitis, zob.: V. Biržiška, Aleksandrynas. Senujų lietuviu rašytojų, rašiusiu prieš 1865 m., biografijos, bibliografijos ir biobibliografijos, T. II, op.cit., s. 73. Podobnie rzecz się miała z nazwiskiem Baranauskasa.

${ }^{11}$ O. Kolberg, Dzieła wszystkie, T. 53. Litwa, Wrocław-Poznań 1966, s. 70.

${ }^{12}$ Lithuanian Literature, red. V. Kubilius, Vilnius 1997, s. 40.
} 
a Maironisem ${ }^{13}$ i dalej: Wyrażając w swojej twórczości poetyckiej najżywsze dążenia narodu i dowodzac dyspozycji języka litewskiego, dat mocny impuls dla rozkwitu litewskiej romantycznej poezji lirycznej ${ }^{14}$. Można jedynie dodać, że wpływ Baranauskasa - i na tym polu też spotykał się ze swoim poprzednikiem - nie ograniczał się do zaproponowania wzorca poetyki w ramach jednego prądu estetycznego. Przykład biskupa sejneńskiego, pomiędzy niewieloma innymi, w tym Donelaitisa, wyznaczał kontekst i dawał motywację pierwszemu dającemu się historycznie wyodrębnić pokoleniu pisarzy, publicystów i wydawców litewskich, aktywnemu na przełomie XIX i XX stulecia. Twórcy ci w realiach zaboru rosyjskiego, wobec wyjątkowej represji, jaką był wprowadzony przez administrację carską po upadku powstania styczniowego zakaz druku czcionką łacińską na obszarze guberni litewskich, podjęli trud budowania, czy też zreaktualizowania własnej tożsamości politycznej i kulturowej, zapisany w dziejach pod nazwą ruchu litewskiego odrodzenia narodowego, którego istotną emanacją była unikatowa w tym czasie w skali całej Europy działalność przemytników książek ${ }^{15}$.

Był to wpływ długofalowy, nierównomierny, zapośredniczony niejako przez perypetie bibliograficzne. Otóż oba poematy, którym w XX wieku przyznano miano ,klasycznych“, długo czekały na przygotowanie do druku przez litewskich redaktorów, na samodzielne

${ }_{13}$ Lietuviu literatūros istorija XIX amžius, red. J. Girdzijauskas, Vilnius 2001, s. 707. Maironis, właśc. Jonas Mačiulis (1862-1932) - duchowny, długoletni rektor kowieńskiego Seminarium Teologicznego, poeta, dramaturg, autor prac naukowych. Uznawany za najwybitniejszego i najbardziej dojrzałego przedstawiciela litewskiego romantyzmu, mimo że większość jego utworów powstała pod koniec XIX i w pierwszych dekadach XX wieku.

${ }^{14}$ Ibid., s. 726.

${ }^{15}$ Zjawiska te, późniejsze wobec tu opisywanych, przedstawiam m.in. w tekstach: M. Niemojewski, Knygnešiai, czyli o narodzinach litewskiej inteligencji, [w:] Sploty kultury, red. N. Dołowy-Rybińska i inni, Warszawa 2010; M. Niemojewski, Jonas Basanavičius - szkic do narodzin litewskiej myśli politycznej i kulturalnej, [w:] Stosunki polsko-litewskie wczoraj i dziś. Historia, kultura, polityka, red. W.K. Roman, J. Marszałek-Kawa, Toruń 2009. 
publikacje. W XIX wieku budziły zainteresowanie edytorów w dużej mierze jako materiały pomocne w studiach językoznawczych i etnograficznych. Już wspomniane wydanie pieśni Donelaitisa, przygotowane przez Rėzę, miało charakter prezentacji tekstu ważnego z perspektywy lingwistycznej; zbliżoną funkcję pełniły edycje niemieckie, zawierające oryginalną wersję językową, zredagowane przez A. Schleichera (w 1865 r.), G.H.F. Nesselmanna w 1869 r. i L. Passarge'a z 1894 roku $^{16}$. Na podstawie tych opracowań wydali spuściznę Donelaitisa litewscy inteligenci, przebywający na emigracji w Stanach Zjednoczonych ${ }^{17}$. Autonomicznie ,literackiego” wydania czytelnicy na Litwie doczekali się dopiero na początku XX stulecia, w 1909 roku $^{18}$.

Podobnie potoczyły się losy utworu Baranauskasa. Co prawda w druku ukazał się po raz pierwszy, podzielony na części, w litewskich publikacjach - kalendarzach L. Ivinskisa na rok 1860 i $1861^{19}$, ale pierwsza część w ogóle nie była podpisana, druga zaś opatrzona pseudonimem. Za życia autora edycji samoistnych i litewskich już nie było, poemat został natomiast opublikowany przez językoznawców, Leopolda Geitlera w Pradze w 1875 roku i Hugo Webera w Weimarze w 1882 roku, przy czym obu redaktorów skusiła głównie możliwość wykorzystania rzadkiego przykładu poezji w języku litewskim

${ }^{16}$ A. Schleicher, Christian Donaleitis Litauische Dichtungen, St. Petersburg 1865; G.H.F. Nesselmann, Christian Donalitius Littauische Dichtungen nach Königsberger Handschriften, Königsberg 1869; L. Passarge, Christian Donalitius 'Littauische Dichtungen, Halle 1894. Zwracają uwagę różnice w zapisie nazwiska - nawet niemieccy filologowie nie ustalili wtedy jednej przyjętej formy. W odróżnieniu od innych niekonsekwencji w przywołanych tytułach, pisownia nazwiska litewskiego poety nie wiązała się z procesami lingwistycznymi w obrębie języka niemieckiego.

${ }^{17}$ K. Donelaitis, Rasztai, red. A. Burba, A. Milukas, Shenandoah 1897.

${ }^{18}$ K. Donelaitis, Raštai. Pagal Rèzos, Šleicherio ir Neselmano sutaisé J. Šlapelis, Vilnius 1909. Jak wynika z tytułu, pierwsze wydanie litewskie opierało się na wersjach niemieckich.

${ }^{19}$ Tym wydawnictwom poświęciłem tekst Litewskie kalendarze $w$ drugiej połowie XIX wieku: inicjacje wspólnoty praktyków słowa drukowanego, [w:] Antropologia praktyk językowych, red. G. Godlewski, A. Karpowicz, Warszawa 2016. 
w badaniach nad dialektami bałtyjskimi ${ }^{20}$. I ponownie pełne, osobne wydanie adresowane do czytelnika litewskiego ukazało się dopiero w pierwszej dekadzie nowego wieku, w 1905 roku w Wilnie ${ }^{21}$, już po śmierci Baranauskasa i w kilka miesięcy po legalizacji wydawnictw litewskich. Co nie znaczy, że dzieło Baranauskasa pozostawało anonimowe i nieznane za jego życia. Oba teksty - Donelaitisa i Baranauskasa - były znane wykształconym Litwinom jeszcze przed tymi edycjami, które nazwać można krajowymi, o czym świadczą wzmianki we własnych publikacjach przedstawicieli przywołanego wyżej pokolenia ${ }^{22}$, w archiwach pierwszych litewskich czasopism, w korespondencji instytucjonalnej i prywatnej ${ }^{23}$. Trudno jednak z całą pewnością stwierdzić, jaki był rzeczywisty zasięg tej recepcji. Do społeczności wiejskich mogły dotrzeć kalendarze Ivinskisa z poematem księdza biskupa, przemycano jego wiersze ${ }^{24}$, natomiast we wspomnieniach chłopskich uczestników ruchu przemytniczego brak sygnałów wskazujących na znajomość twórczości Donelaitisa w latach przed zniesieniem zakazu druku. Poematy oddziaływały więc przede wszystkim w gronach inteligentów zaangażowanych w działalność kulturalną, często przez samą świadomość ich istnienia.

Wydania wileńskie poszerzyły znacznie krąg odbiorców dzieł Donelaitisa i Baranauskasa, stały się punktem odniesienia do kolejnych, poprawianych edycji i zainicjowały recepcję krytyczną twórczości tych autorów, kontynuowaną, uzupełnianą i rozszerzaną do dzisiaj. Jeden z tematów rozważań badawczych daje asumpt do ponownego

${ }^{20}$ Anykszcziu szilelis, [w:] L. Geitler, Litauische Studien, Prag 1875, s. 40-48; A. Baranowski, Anykszczu szilelys, [w:] A. Weber, Ostlitauische Texte, Weimar 1882, s. 1-23.

${ }^{21}$ A. Baranauskas, Anykščiu šilelis, red. J. Jablonskis, Vilnius 1905.

${ }^{22}$ Zob.: J. Šliupas, Lietuviszkiejie rasztai ir rasztininkai, Tilžè 1890, s.20-22 oraz 81-84.

${ }^{23}$ Kwestię tę w odniesieniu do Baranauskasa omawia E. Aleksandravičius, Antanas Baranauskas..., op.cit., rozdz. Jutrzenka czy zmierzch.

${ }^{24}$ Zob.: Knygně̌ys, T. II, red. P Ruseckas, Vilnius 1992, s.12. 
zestawienia dokonań obu litewskich poetów. Chodzi mianowicie o hipotezy dotyczące genezy przywołanych tu poematów, a ściślej, o przekazy mówiące o okolicznościach ich powstawania, obarczone statusem legend literackich, na tyle jednak prawdopodobne i często przywoływane, że zmusiły badaczy przynajmniej do odnotowywania tych wersji, a często również do prób ich przeanalizowania.

Do podstawowych problemów, z jakimi zmagają się komentatorzy spuścizny Donelaitisa, należą pytania, czy litewski pastor brał w ogóle pod uwagę ogłoszenie swojego najważniejszego dzieła drukiem, czy postrzegał je jako artystyczną całość, czy też uważał poszczególne pieśni za osobne utwory, tworzone jako wprawki literackie lub w jakimś innym celu, związanym z pragmatycznie pojmowaną piśmiennością, z pisaniem w kontekście innych działań? Dotychczas udzielane odpowiedzi mają rangę hipotez, opierają się bowiem na skromnym materiale, który nie daje nawet podstaw do jednoznacznego ustalenia, kiedy Pory roku, a ściślej poszczególne części, rzeczywiście powstawały. Powszechne w opracowaniach wskazanie okresu między 1765 a 1775 rokiem jako czasu powstania rękopisów wynika z interpretacji źródeł pośrednich i analizy filologicznej zachowanych tekstów, jest to jednak datowanie orientacyjne, odbiegające od założeń pierwszych wydawców ${ }^{25}$. Szukając rozstrzygnięcia tych wątpliwości, badacze powracają do spekulacji, jakoby Donelaitis wykorzystywał zapisane już fragmenty przyszłego poematu w kazaniach wygłaszanych do swoich wiernych w Tolminkiemis, a być może nawet tworzył wierszowany tekst z takim przede wszystkim zamiarem. Podłożem takiego odczytania dzieła są zarówno dokumenty archiwalne związane z pracą duszpasterską Donelaitisa, jak i poetyka oraz konstrukcja poematu. Przekonując, że nie ma podstaw, aby mniemać, że Donelaitis pisat „Pory roku” tylko po to, by zaspokoić literackie oczekiwania

${ }^{25}$ Analizowali ten problem m.in. L. Gineitis, Kristijonas Donelaitis ir jo epocha, Vilnius 1964 oraz A. Jovaišas, Kristijonas Donelaitis: gyvenimas ir kūryba, Kaunas 1992. 
kręgu swoich przyjaciót, Leonas Gineitis podkreślał: Na jego plastyczne słowo poetyckie czekała nie tylko grupka znajomych, czekali na nie również słuchacze niedzielnych kazań-litewscy chłopi z Prus ${ }^{26} \mathrm{i}$, by tę konstatację wesprzeć źródłowo, cytował fragment z protokołu wizytacji parafii, przeprowadzonej w 1774 roku przez dziekana Miulerisa (zapewne Müllera): [Donelaitis] wygłasza kazania po litewsku i po niemiecku, a te po litewsku - wprost z maestria ${ }^{27}$. Dodawał przy tym, że podobne wpisy pojawiały się w kolejnych protokołach wielokrotnie, a i w zachowanych zapiskach samego Donelaitisa znajdował uwagi świadczące o pierwotnie ustnym wykorzystaniu wierszowanego tekstu, dotyczące poprawek, które autor musiał nanosić, gdyż Litwini od razu wychwytywali wszelkie usterki gramatyczne i dialektalne. Litewski badacz podsumowywał swój wywód następująco: (...) fragmenty swojego poematu Donelaitis z pewnościa zaadresowat do chłopów, a najprawdopodobniej im je odczytywat, szukając weryfikacji poetyckiego brzmienia swojego dzieła przed szeroka wiejska publicznością ${ }^{28}$.

Tym samym tropem, ale znacznie wcześniej, podążał Vaclovas Biržiška. W 1944 roku, na łamach wydanego w warunkach okupacyjnych almanachu „Varpai“, litewski historyk literatury opublikował po raz pierwszy w całości zachowane fragmenty broszury z 1769 roku, przypisywanej Donelaitisowi ${ }^{29}$ jako autorowi oryginalnego tekstu lub tłumaczenia z języka niemieckiego. Dokument ten, znany obecnie jako Brošiura apie separacijos nauda ${ }^{30}$, dotyczył bieżących sporów o rozdział gruntów, w które zaangażowany był Donelaitis jako administrator parafii i adresowany był, w formie odezwy, przede wszyst-

\footnotetext{
${ }^{26}$ L. Gineitis, op.cit., s. 204-205.

${ }^{27}$ Ibid.

${ }^{28}$ Ibid.

${ }^{29}$ V. Biržiška, Nežinomas 1769 m. Donelaičio spaudinys, [w:] Varpai. Literatūros almanachas, Šauliai 1944, s. 44.

${ }^{30}$ Wersję poprawioną i uznawaną za najdokładniejszą znaleźć można w wydaniu zbiorowym: K. Donelaitis, Raštai, red. Kostas Korsakas, Vilnius 1977, s. 279.
} 
kim do miejscowych gospodarzy. W ocenie Biržiški podstawowym argumentem, przemawiającym za autorstwem Donelaitisa był fakt, że w tekście broszury znalazły się dwa wersy, pochodzące z jednej $\mathrm{z}$ ksiąg poematu ${ }^{31}$. Badacz przekonywał, że: (...) te dwa powyższe wersy to nie styl Donelaitisa i jego język, lecz po prostu autentyczny Donelaitis: słowo $w$ stowo, litera po literze wersy te zostały wzięte $z$ „Pór roku” Donelaitisa (... $)^{32}$. Wyjaśniał przy tym, że na taki cytat mógł sobie pozwolić tylko autor poematu, bo jego rękopis nie był w tym czasie powszechnie znany.

Najważniejsze z punktu widzenia rozważanej tu kwestii było stwierdzenie, że dokument ten, nawet jeśli był przełożoną na litewski bardzo swobodnie wersją niemieckiego oryginału innego autora ${ }^{33}$, należy jednak postrzegać jako (...) popularna, przeznaczona dla ludu ksiązeczkę, w której autor starat się $w$ prostych i zrozumiatych zdaniach nakłonić chtopów do podzielenia się wspólnymi pastwiskami $(\ldots)^{34}$. Twórca poematu nie czynił więc rozróżnienia między literaturą a doraźną publicystyką o zasięgu lokalnym. W jednym i drugim przypadku posługiwał się tym samym językiem, a fraz wierszowanych, zapisanych $\mathrm{w}$ pieśni poematu, używał w funkcji epigramatycznego zwieńczenia fragmentu agitacji skierowanej do tej samej grupy odbiorców, do której wygłaszał kazania.

Również stylistycznie Pory roku odbiegały od konwencji estetycznej epoki. Donelaitis próbował co prawda skonstruować litewski heksametr, wykorzystując właściwości prozodyczne języka litew-

${ }^{31}$ Autor broszury zacytował dwa wersy z części opatrzonej tytułem Trudy lata: Czy nie wiesz, że chłop ziarna pragnac zebrać sporo/Wpierw musi ziemię swoja nawozem nasycić?; cyt. za: K. Donelaitis, Pory roku/Metai, thum. Z. Lawrynowicz, Olsztyn-Białystok 1982, s. 67 (wydanie dwujęzyczne).

32 V. Biržiška, Nežinomas 1769 m. Donelaičio spaudinys, [w:] Varpai. Literatūros almanachas, op.cit., s. 47.

${ }^{33}$ Biržiška wątpił w zasadność takiej tezy. Uważał, że Donelaitis mógł sporządzić tekst w dwóch wersjach językowych.

${ }^{34}$ V. Biržiška, Nežinomas 1769 m. Donelaičio spaudinys, op.cit., s. 48. 
skiego, ale jego realistyczne podejście do przyrody i życia na wsi drwiło z klasycznych kanonów, jak zauważył polski tłumacz utworu ${ }^{35}$. Całość to rozpisana na głosy mieszkańców wsi (w utworze dominują monologi wypowiadane przez poszczególnych gospodarzy) dydaktyczna i utrzymana w duchu kaznodziejskiego pouczenia opowieść o trudach i powinnościach wiejskiej egzystencji, determinowanych przez cykl natury. Trudno w tych strofach znaleźć wyrafinowane środki retoryczne, właściwe kazaniom jako gatunkowi literackiemu. Dziełu Donelaitisa bliżej jest do pieśni przywoływanych przez Alberta Lorda, niż do poświęconych podobnej tematyce przykładów z literatury niemieckiej, francuskiej czy angielskiej tego okresu, i kiedy je z nimi porównywano, to na ogół po to, by wskazać, jak bardzo na ich tle jest oryginalne ${ }^{36}$. Dominuje w nim język dosadny, potoczny, żywy i sytuacyjny, bogaty we frazy formuliczne, nagromadzenia, charakterystyczne dla mowy litewskiej zdrobnienia. Zamiast skonwencjonalizowanego obrazu czytelnik - a może przede wszystkim słuchacz - otrzymywał chłopskie gawędzenie, ujęte w dramaturgię naturalnego i obrzędowego porządku gospodarskiego losu:

My, łapciowi Litwini, boże niebożęta,

Panom i stugom ich nam dorównać nie sposób,

Lecz pańskich chorób także szczęśliwie nie znamy.

A ilez to niemocy po dworach $i$ w mieście,

Kiedy tak lato do nas powoli się zbliża.

(...)

My zaś chlopi, choć w mieście nas maja za tajno,

Napiwszy się serwatki lub maślanki czystej

Prace nam wyznaczone odrabiamy pędem,

A jeśli czasem kąsek uda się stoniny

${ }^{35}$ K. Donelaitis, Pory roku, op.cit., s. XXXVII.

${ }^{36}$ Do Jamesa Thomsona, XVIII-wiecznego poety szkockiego, autora poematu Seasons, porównywał Donelaitisa m.in. L. Gineitis, op.cit., s. 233 i następne. 
Lub kietbasy litewskiej skosztować kawatek, To ta chtopska robota pali nam się w rękach ${ }^{37}$. I dalej:

Nie znamy bowiem zimy nadchodzacej granic I co przed Wielkanoca zostanie nie wiemy.

Czy to nie radość ludziom, gdy ścierpiawszy zime W spizarni jeszcze maja wszystkiego po trochu? Teraz juz dość gadania, bo rozejść się pora! Ty, dobry Panie Boże, spraw, byśmy po świętach Sylwestra doczekawszy $w$ zdrowiu $i$ weselu Zeszli się jak sasiedzi stów zamienić parę ${ }^{38}$.

Realizm poematu, czy też, co będzie chyba trafniejszym określeniem, skrupulatność w opisie codzienności chłopskiej, sporządzonym do tego w języku nie poddanym ani gruntownemu artystycznemu przetworzeniu, ani nawet stylizacji, a w zasadzie zaczerpniętym z przedstawianej rzeczywistości - te cechy próby poetyckiej Donelaitisa upoważniały badaczy do podkreślania jej swoistości, „narodowego charakteru" i niezależności od obowiązujących w epoce wzorów poetyki, ale równocześnie domagały się wyjaśnienia. Dzieło, zaliczone wszak do najbardziej wartościowego dziedzictwa litewskiej literatury pięknej, analizowane było w kategoriach historycznoliterackich, które wyznaczały granice rekonstrukcji kontekstów. Rozszerzenie tej rekonstrukcji dokonało się właśnie dzięki legendzie, która z czasem urosła do rangi prawomocnego wątku interpretacyjnego. Na ogół w takich wariantach, które pozwalały na zachowanie perspektywy literaturoznawczej. Juozas Grinius tak próbował wyjaśnić kwestię genezy utworu Donelaitisa: Czasami badacze pisza, że odczytywat on fragmenty poematu podczas kazań. A mogło przecież być odwrotnie.

${ }^{37}$ K. Donelaitis, Pory roku, op.cit. s. 53.

${ }^{38}$ Ibid. s. 159. 
Może właśnie dlatego wiele fragmentów poematu wydaje się nanizanych na nić nauczania ${ }^{39}$.

Z kolei przywoływany już Gineitis w swoich pracach poświęconych Donelaitisowi konsekwentnie powracający do tematu nauk wygłaszanych z ambony, równie konsekwentnie objaśniał to powiązanie jedynie zaangażowaniem poety-duchownego w sprawy społeczne i przytaczał przykłady podobnego wykorzystania tekstu poetyckiego, zaczerpnięte z dziejów innych literatur europejskich. Różne są zatem sposoby rozwinięcia wspomnianego wątku, w żadnej jednak z akademickich analiz dzieła Donelaitisa nie kwestionuje się istnienia bardzo istotnego związku między praktykami kaznodziejskimi pastora a jego dokonaniami literackimi - do czego trzeba będzie za chwilę powrócić.

Najpierw jednak należy przypomnieć drugą z legend, dotyczącą tym razem najbardziej znanego utworu poetyckiego Baranauskasa. W tym przypadku nie ma problemu ze wskazaniem jej źródła. W almanachu literackim Gabija, przygotowanym przez skupiony wokół Józefa Herbaczewskiego krąg studentów litewskich w Krakowie i wydanym tamże w 1907 roku, a zadedykowanym pamięci Baranauskasa, zamieścił swoje wspomnienia o biskupie sejneńskim jego admirator, a zarazem antagonista, duchowny, teolog i krytyk literacki, Adomas Jakštas ${ }^{40}$. Pisał w niej o lekcjach homiletyki w seminarium w Worniach, które prowadził w latach nauki Baranauskasa ksiądz Antanas Gabšys (w polskich i niektórych litewskich opracowaniach wymieniany też jako Antoni Gabszewicz). Jedną z nich opisał dokładniej:

Na jednej z takich lekcji ksiądz Gabšys, przeczytawszy z „Pana Tadeusza" opis puszczy litewskiej, zacząt wychwalać piękno języka poetyckiego tego dzieta, a potem skierowat rozmowe na kwestięję-

\footnotetext{
${ }^{39}$ J. Grinius, Veidai ir problemos lietuviu literatūroje, Roma 1973, s. 28.

${ }^{40}$ Adomas Jakštas, właśc. Aleksandras Dambrauskas (1860-1938) - duchowny katolicki, poeta, krytyk, filozof, publicysta. W pierwszej dekadzie XX wieku jego artykuły krytyczne o literaturze i sztuce, publikowane na łamach czasopism litewskich, cieszyły się popularnością wśród czytelników i miały moc opiniotwórczą.
} 
zyka polskiego, i zacząt szeroko objaśniać, jak piękny jest to język, jak bogaty, jakie ma finezyjne brzmienie itd. Klerycy stuchali tego nadstawiając uszu, niczym stów proroka. I gdyby ksiądz profesor na tym zakończyt, lekcja zrobiłaby na wszystkich jak najlepsze wrażenie. Ale on popetnit poważny błąd taktyczny: wynoszac pod niebiosa język polski, zaczą okrutnie drwić z litewskiego, że w nim nie można wyrazić jakiejkolwiek wznioślejszej myśli, że do poezji on zupetnie nie pasuje itd., itd. Krótko mówiąc, pohańbit i zbezcześcił język litewski tak, jak tylko wynarodowiony Litwin może to zrobić. Jak się podobała ta lekcja innym klerykom, nie wiadomo. Ale dla A. Baronasa [taka pisownia nazwiska w oryginale-przyp. M. N.] to byłojak cios nożem w serce. (...)

Dlatego nie spocząt, dopóki tego samego lata 1858 roku, przyjechawszy do domu, nie napisat pierwszej części „,Borku oniksztyńskiego", a nastepnego lata-drugiej.

W ten sposób „Borek oniksztyński”, zgodnie z zamiarem A. Baronasa, stat się jakby argumentum ad hominem, za pomoca którego nasz wieszcz nie tylko swoim szkolnym kolegom, ale całej Litwie udowodnit, że nasz język nie jest ani trochę marniejszy niż polszczyzna, wprost przeciwnie, że wydaje sie jeszcze bogatszy i doskonalszy, że można w nim wyrazić wszelkie piękno poezji i najszlachetniejsza myśl, i właśnie dlatego wszyscy Gabšysowie et consortes to zwyczajni nikczemnicy i kłamcy.

Taka oto była geneza „Borku oniksztyńskiego”41.

Cytat to dosyć długi, ale relacja Jakštasa zasługuje na tak obszerne przytoczenie, jest bowiem właściwie jedynym przekazem ujawniającym przyczyny powstania najważniejszego litewskiego poematu drugiej połowy XIX wieku. Nie udało się ustalić, gdzie i od kogo ten

\footnotetext{
${ }^{41}$ A. Jakštas, Kas ikvepe A. Baronui „Anykščiu šilelị"?, [w:] Gabija. Rinktine knyga, paaukota lietuvos dainiaus vyskupo Antano Baranaucko atminimui, knyga sutaisè ir spaudai prirengé Juozapas Gerbačauskis, Kraków 1907, s. 24-25.
} 
bardzo aktywny na przełomie stuleci uczestnik litewskiego życia kulturalnego usłyszał tę historię, choć w toku badań powstała hipoteza, że opowiedział mu ją sam Baranauskas ${ }^{42}$. Nie jest to zresztą kwestia wymagająca tutaj rozstrzygnięcia. Ważniejsze jest, że opowieść księdza Jakštasa pojawiła się w momencie, gdy polaryzowały się wśród Litwinów postawy wobec życia i twórczości zmarłego w 1902 roku Baranauskasa - dla jednych pozostawał przede wszystkim mistrzem litewskiego wiersza, dla innych, zwłaszcza dla współtworzących ruch odrodzenia narodowego, był niemal zdrajcą sprawy narodowej jako ten, który najpierw rozbudził nadzieje i pragnienia swoją litewskojęzyczną twórczością, a potem sprzeniewierzył się tej idei dla kościelnych godności i poparcia ze strony jego polskich sprzymierzeńców ${ }^{43}$.

Ówczesny dramat biskupa sejneńskiego przedstawiał m.in. Tomas Venclova: Recepcja wierszy Baranauskasa-a w pewnym stopniu, nawiasem mówiąc, i Mickiewicza-miała charakter paradoksu. Pokolenie , litwomanów” włączyło je do swego systemu. Demokratyczne $i$ narodowe odrodzenie poczytywat Baranauskas - wraz z wieloma polskimi działaczami-za herezje, a w najlepszym wypadku-za infantylne igraszki; przywódcy zaś owego odrodzenia karmili się wierszami jego młodości, cytowali je i ku świętemu oburzeniu sędziwego autora publikowali w swoich czasopismach. Zaszło jakby rozdwojenie osobowości, przeciwstawienie dwóch jej czasowych przekrojów: młody poeta Baranauskas okazat się inspiratorem ruchu, który w żadnej mierze nie cieszyt się przychylnościa starego biskupa ${ }^{44}$.

\footnotetext{
${ }^{42}$ Zwolenniczką takiego wyjaśnienia jest Regina Mikšytė, zob.: tejże: Antanas $B a-$ ranauskas, Vilnius 1993, s. 71 i dalsze.

${ }^{43}$ Należał do nich J. Basanavičius, który na kartach tego samego almanachu, w artykule wstępnym, kreśląc portret Baranauskasa jako niekwestionowanego klasyka literatury litewskiej, równocześnie poddawał nieco tylko złagodzonej krytyce jego wybory życiowe, językowe i polityczne, zob.: Dr J. Basanavičius, Prakalbosvieton, [w:] Gabija..., op.cit., s. 1-3.

${ }^{44}$ T. Venclova, Mit o początku, przeł. R. Śliwowski, [w:] tegoż, Kształty nadziei, Warszawa 1985, s. 144.
} 
Wypowiedź Jakštasa, przygotowana z myślą o pamiątkowym almanachu, była zapewne świadomym głosem w tym sporze. Mimo że nie została przez nikogo ostatecznie zweryfikowana, zajęła trwałe miejsce w dyskusjach i refleksji nad dorobkiem literackim litewskiego klasyka, a w szerszym ujęciu - podobnie jak hipoteza o homiletycznej genezie poematu Donelaitisa - w rozważaniach o narodzinach i rozwoju literatury litewskiej oraz kształtowaniu się, czy też intensyfikowaniu się, odrębności kulturowej i tożsamości narodowej Litwinów. Ale obie legendy mogą prowadzić również ku inaczej określonej perspektywie.

Z przedstawionych analogii i różnic w losach obu twórców i ich dzieł wyłania się bowiem obraz kolejnej dającej się wyróżnić epoki w dziejach litewskiego piśmiennictwa, rozumianych tutaj nie jako „klasyczna” historia literatury, ale jako proces formowania się umysłowości piśmiennej, czy ujmując rzecz precyzyjniej, jako stopniowe i przebiegające nierównomiernie w strukturze społecznej przechodzenie od oralności do piśmienności z jej implikacjami dla jednostek i grup społecznych ${ }^{45}$. Epoki tej nie wyróżniają jako osobnej litewskie kompendia historycznoliterackie, ale też ich autorzy nie przyjmowali wskazanej wyżej płaszczyzny opisu ${ }^{46}$. A właśnie z tego, sformułowanego przez teoretyków piśmienności punktu widzenia, wolno uznać okres dzielący powstanie Pór roku od powstania i opublikowania Borku oniksztyńskiego za samoistny i doniosły. Poprzedzał on bezpośrednio lata rozkwitu ruchu narodowego i czas przemytników książek, a przede wszystkim konstytutywną dla tych zjawisk ekspansję sło-

\footnotetext{
${ }^{45}$ Używając tych kategorii, nie odwołuję się bezpośrednio do konkretnej propozycji teoretycznej, lecz raczej do obszaru problemowego, wyznaczonego przez konfigurację tekstów poświęconych teorii piśmienności. Szczegółowe podsumowanie różnych kierunków i wariantów tej teorii zawiera praca Grzegorza Godlewskiego Słowo - pismo - sztuka słowa. Perspektywy antropologiczne, Warszawa 2008.

${ }^{46} \mathrm{~W}$ godnym odnotowania stopniu przełamują ten schemat najnowsze opracowania zbiorowe, przede wszystkim cytowane już wcześniej dzieło zbiorowe Lietuviu literatūros istorija XIXamžius, red. J. Girdzijauskas, Vilnius 2001.
} 
wa drukowanego w przestrzeni języka litewskiego. Uformowała się w nim społeczność uczestników, realizatorów tych przemian, coraz bardziej świadomych, że pisanie, drukowanie, czytanie i rozprzestrzenianie tekstów może służyć konstruowaniu wizji rzeczywistości i porządkowaniu, a w rezultacie ukierunkowaniu wiedzy o świecie, w pierwszej kolejności najbliższym, własnym, litewskim.

Konstatacja następna niech będzie ostateczną tezą tego tekstu: w tym okresie zainicjowane zostały działania i sformułowane idee, których instrumentem był rękopis i druk, a celem - wypełnienie treścią nieprzejrzystej wtedy dyspozycji, nazywanej później tożsamością narodową, oraz urzeczywistnienie tej dyspozycji w postaci „obiektywizującej własne doświadczenie" 47 zbiorowości z jednej strony i projektu jej instytucjonalizacji, czyli społeczno-politycznej autonomii, z drugiej.

Mechanizmy „galaktyki Gutenberga” w litewskiej kulturze literackiej, w jej litewskojęzycznej warstwie ${ }^{48}$, były już obecne wcześniej, przynajmniej w sferze akademickiego zainteresowania językiem i w myśli religijnej. W tym okresie osiągnęły jednak szczególne natężenie i wykroczyły poza ramy tych dwóch dziedzin. Granice tak rozpoznanej epoki - mające, rzecz jasna, charakter orientacyjnie przyjętych konturów propozycji teoretycznej - wyznaczały dokonania literackie Donelaitisa i Baranauskasa, nie tyle ze względu na odmienność reprezentowanych przez ich utwory poetyk, ile ze względu na to, co zasadniczo odróżnia układy kontekstów, w których powstawały. Z porównania tych kontekstów, prześledzenia ich przeobrażeń, wypłynąć może bowiem odpowiedź na bardziej podstawowe pytanie, a mianowicie czy różni się, a jeśli tak, to czym się różni, „literackość”

\footnotetext{
${ }^{47}$ Zob.: J. Goody, I. Watt, Następstwa piśmienności, przeł. J. Jaworska, [w:] Communicare. Almanach antropologiczny. T. II: oralnośćl piśmienność, Warszawa 2007, s. 67.

${ }^{48}$ Podkreślenie to jest potrzebne, by wyodrębnić piśmiennictwo w języku litewskim z całej literatury powstającej o Litwie i na obszarze dawnego Wielkiego Księstwa w tym okresie w innych, znacznie wcześniej „upiśmiennionych” językach.
} 
spuścizny obu poetów, zaliczonej przecież do kanonu literatury litewskiej jako części literatury powszechnej.

Przyjmijmy najpierw za Grzegorzem Godlewskim, że (...) do zbadania literatury jako zjawiska kulturowego niezbędne jest (...) skonfrontowanie wizerunku literatury z innymi formami sztuki słowa, nie tylko umiejscowionymi w odmiennych kulturach, ale też umiejscowionymi inaczej ${ }^{49}$, z tym jednakże uzupełnieniem ${ }^{50}$, że ,inne formy sztuki słowa” mogą oznaczać także ,inaczej umiejscowione” typy literatury utrwalonej, przynajmniej w finalnej fazie swojego istnienia, w druku, i że konfrontacja może przebiegać wzdłuż nieoczywistych wcale osi. Wyjaśnienie, dlaczego dla tej epoki pierwszą cezurą miałaby być twórczość Donelaitisa, warto więc rozpocząć wskazówką z dość odległego, jeśli chodzi o kształt i rozległość czasoprzestrzenną tradycji literackiej, kręgu kulturowego.

W szkicu pełniącym funkcję wstępu do polskiego wydania Charakterów Jeana de La Bruyère'a, Roland Barthes sugerował: (...) można też czytać go, podkreślając to wszystko, co dzieli jego świat od naszego i co owa odległość mówi nam o nas samych ${ }^{51}$. Choć Bruyère to nieco zapomniany pisarz początków francuskiego oświecenia, przedstawiciel specyficznie francuskiego nurtu „moralistów”, reprezentujący jedną z najmocniej zakorzenionych w historii i najzasobniejszych literatur europejskich, zadziwiająco wiele uwag Barthesa na jego temat można odnieść do litewskiej, i nie tylko litewskiej, recepcji Donelaitisa: szkoła przywiąuje do niego wielka wage, jego maksymy, kunszt, rola historyczna - stanowia tematy wypracowań, ale nawet krytyka

${ }^{49}$ G. Godlewski, Słowo - pismo - sztuka słowa. Perspektywy antropologiczne, Warszawa 2008, s. 328.

${ }^{50}$ Uzupełnienia w takiej postaci wymaga jedynie niniejszy wywód, nie cytowana teoria. W pracy Godlewskiego znajduje ono wielokierunkowe rozwinięcie w innym fragmencie przywołanej wyżej książki, zob.: rozdział Literatura i ,literatury", [w:] G. Godlewski, op.cit., s. 265-317.

${ }^{51}$ R. Barthes, La Bruyère: od mitu do literatury, [w:] J. de La Bruyère, Charaktery, przeł. A. Tatarkiewicz, Warszawa 1965, s. 11. 
niewiele troszczyła się o to, aby odnowić jego szkolarski obraz, jego dzieło nie pobudziło historyków, socjologów, filozofów ani psychoanalityków, sława jego jest nieco senna, w końcu należy do nas przez swoja anachronicznośc ${ }^{52}$. Charakterystykę współczesnego odbioru La Bruyère'a przeprowadza Barthes w konkretnym celu, bo pozwala mu ona sformułować zasadniczy problem eseju: Sadzimy dziś, że literatura to technika, zarazem głębsza niż styl i bardziej bezpośrednia niż myśl; sądzimy, że jest ona zarazem słowem i myśla; myśla, która szuka na poziomie słowa, słowem, które wgląda w siebie. Czy tym właśnie jest La Bruyère? ${ }^{53}$. I dalej, w toku analizy, zasugerować jego rozwiązanie, które da się pokrótce przedstawić następująco: dzieło Bruyère'a jest anachroniczne, opisywany przez niego świat i kategorie tego opisu są tak odległe, że stają się czytelnikowi właściwie obojętne, obcy jest styl i nawet postać gatunkowa, majaca niewiele odpowiedników w naszej literaturze nasyconej doskonałościa gatunków ściśle określonych ${ }^{54}$, krótko mówiąc, współczesność nie potrafi go nazwac ${ }^{55}$. Jego poczesne miejsce w dziejach literatury tłumaczy co innego: Dla La Bruyère' a być pisarzem to wierzyć, że w pewnym sensie treść zależy od formy $i \dot{z}$ e opracowujac oraz modyfikujac struktury formalne można osiagnać pewne szczególne zrozumienie rzeczy, oryginalne ujęcie rzeczywistości; krótko mówiąc-nowy sens; język sam w sobie jest dla niego światopogladem ${ }^{56}$. Akces francuskiego moralisty do literatury polegał na wykorzystaniu języka w taki sposób, aby uzyskać pewien zobiektywizowany, nasycony pierwiastkiem etycznym, pouczający zapis znanych mu realiów. Po to, jak stwierdza Barthes, La Bruyère zdecydował się zostać pisarzem.

\footnotetext{
${ }^{52}$ Ibid., s. 10-11.

${ }^{53}$ Ibid., s. 21.

${ }^{54}$ Ibid., s. 24.

${ }^{55}$ Ibid., s. 10.

${ }^{56}$ Ibid., s. 26.
} 
$\mathrm{Z}$ analogicznym dylematem mamy do czynienia w przypadku Donelaitisa i całkiem zasadne wydaje się zbliżone jego rozstrzygnięcie. Mimo że Francuz tworzył w zdecydowanie innym uniwersum kulturowym niż Litwin, łączy ich niewspółmierność kryteriów współczesnej analizy historycznoliterackiej do ich dokonań. Charakterystyczne, że dyskusja naukowa poświęcona Donelaitisowi toczy się od lat wokół tych samych. w znacznej mierze pierwszoplanowych, kwestii i nie przynosi jednoznacznych ustaleń.

Badacze zastanawiają się, w jakim stopniu absolwenta studiów teologicznych uniwersytetu w Królewcu (które ukończył w 1740 roku) inspirowały dzieła antycznych mistrzów i poetów mu współczesnych, czy naśladował „Thompsona i Hezjoda, Hallera lub Kleista"57. Litewski pastor miał dostęp do ich utworów, bo, jak przekonywał Leonas Gineitis, w bogatym wyborze znajdowały się wówczas w bibliotece uniwersyteckiej $^{58}$. Zarazem jednak nie pozostawił po sobie księgozbioru, a w nielicznych prywatnych bądź związanych z pracą duszpasterską zapiskach nie zajmował się tematyką związaną z próbami literackimi.

Życie w Tolminkiemis, wiejskiej parafii oddalonej od centrów kulturalnych, nie nastręczało wielu okazji do odświeżenia wiedzy o nowych nurtach intelektualnych $i$ artystycznych, nie licząc kontaktów z kolegami ze studiów, na ogół związanych z tą samą profesją. Nie miał też Donelaitis literackich punktów odniesienia w języku litewskim. W XVIII wieku język litewski pojawiał się wciąż niemal wyłącznie w drukach o charakterze religijnym bądź, bardziej jako materiał do analiz niż medium, w opracowaniach filologicznych. W 1735 roku w Królewcu ukazało się wreszcie pełne wydanie Biblii po litewsku, mające swój odległy początek w nieopublikowanych pra-

\footnotetext{
${ }^{57} \mathrm{Na}$ takie wzorce wskazuje Juozas Brazaitis, zob.: J. Brazaitis, Buros kulturos poetas, [w:] Egzodo Donelaitis: Lietuviu išeiviu tekstai apie Kristijona Donelaiti, Vilnius 2001, s. 14.

${ }^{58}$ L. Gineitis, Ivadas, [w:] K. Donelaitis, Raštai, op.cit., s.7.
} 
cach translatorskich Jonasa Bretkūnasa z końca XVI stulecia i nieco późniejszych próbach Samuelisa Boguslavasa Chilinskisa ${ }^{59}$. Było to przedsięwzięcie zbiorowe, grupujące powiązanych z Albertyną, czyli Uniwersytetem Królewieckim, księży Litwinów lub prowadzących działalność w społeczności litewskojęzycznej ${ }^{60}$. Środowisko to coraz silniej zaznaczało swą obecność w życiu akademickim i kulturalnym dawnych Prus Książęcych, co miało przynieść poważne następstwa w kolejnym stuleciu.

Prócz Biblii, która doczekała się wkrótce następnych, poprawionych wydań, ukazywały się zbiory pieśni religijnych, nierzadko wznawiane, przeredagowywane i będące przedmiotem językoznawczych polemik, zwłaszcza między ich wydawcami, m.in. dobrze znającym litewski Niemcem Gottfriedem Ostermeyerem i Litwinem pruskim Kristijonasem Milkusem. Obaj zaliczali się też do kręgu autorów rozpraw filologicznych. Ostermeyer przygotował i wydał w 1793 roku Erste Litauische Liedergeschichte, a dwa lata wcześniej Neue Litauische Grammatik. Pierwsza historia pieśni litewskich i gramatyka ukazały się jednak po niemiecku, zawierając jedynie przykłady z języka litewskiego. Główny antagonista Ostermeyera, Milkus, wydał z kolei w 1800 roku Kurze Anleitung zur littauische Poesie, rodzaj teoretycznego wprowadzenia do poetyki pieśni litewskich, co ciekawe, ilustrując swoje tezy kilkunastoma wersami z utworu Donelaitisa, które musiał znać ze zmieniającego właścicieli rękopisu.

Te dzieła ukazały się drukiem po śmierci pastora, nie mogły więc wpływać na kształt wersji autorskiej poematu, choć były istotnym wsparciem dla jego wydawcy. Mógł znać natomiast bardzo ważną pracę Pilypasa Ruigysa Betrachtung der litauischen Sprache in ihrem Ursprunge, Wesen und Eigenschaften (Badanie pochodzenia, istoty

\footnotetext{
${ }^{59}$ Biblia litewska Chylińskiego. Nowy Testament-fotokopie, Poznań 1984.

${ }^{60}$ Listę uczestników tej inicjatywy - tłumaczy i redaktorów, prezentuje szczegółowo Pranas Naujokaitis, w tegoż: Lietuvių literatūros istorija. I tomas: Nuo Mažvydo iki Maironio, Nowy Jork 1973, s. 72 i dalsze.
} 
i swoistości języka litewskiego - M. N.) wydaną w 1747 roku, a także broszury Mykolasa Moerlinasa, tłumaczenia bajek Ezopa na litewski, które wyszły spod pióra Jonasa Šulcasa oraz nieliczne oryginalne, krótkie utwory poetyckie w języku litewskim, których autorami byli przedstawiciel przybyłej z Holandii i zasiedziałej w Litwie pruskiej rodziny Schimmelphennigów, Adomas Fridrichas Šimelpenigis (którego nazwisko zapisywane jest już w opracowaniach w brzmieniu litewskim) i wspomniany wyżej Milkus ${ }^{61}$, a także całkiem liczne wznowienia i nowe wersje słowników i gramatyk. Niewykluczone, że znał litewskie druki religijne wydawane w tym czasie w Wielkim Księstwie Litewskim, aczkolwiek, przede wszystkim ze względu na coraz silniejsze polonizowanie się szlachty litewskiej i kleru na tym obszarze, były to publikacje na zdecydowanie niższym językowo poziomie niż wydawnictwa dostępne za północno-zachodnią granicą ${ }^{62}$, a w głównym ośrodku wydawniczym, Wilnie, druki polskojęzyczne zdecydowanie przeważały nad edycjami w rodzimych językach Wielkiego Księstwa ${ }^{63}$. Litewskie piśmiennictwo epoki mogło więc przekonać Donelaitisa o rosnącej, przynajmniej na terytorium Małej Litwy, pozycji języka litewskiego jako przedmiotu badań filologicznych i jako żywego instrumentu w kontaktach z ludnością litewską. Nie dostarczało natomiast wzorców uprawiania literatury w jej artystyczno-ideowej funkcji.

${ }^{61}$ Najważniejsze z tych utworów to krótkie utwory epigramatyczne i list poetycki Šimelpenigisa oraz niewielki poemat historyczny Pilkainis Milkusa. Dokonania te zostały jednak wydane po raz pierwszy dopiero w XX wieku, w okresie międzywojennym: poezje Šimelpinigisa [w:] M. Biržiška, Iš mūsu kultūros ir literatūros istorijos, T. 1, Kaunas 1931, s. 247-260; poemat Milkusa [w:] V. Biržiška, „Tauta ir Žodis“, T. 7, Kaunas 1931, s. 275-283.

${ }^{62}$ Szerzej na temat piśmiennictwa po litewsku i o języku litewskim na obszarze Prus Wschodnich zob.: L. Gineitis, Prūsiškas patriotizmas ir lietuvių literatūra, Vilnius 1995.

${ }^{63}$ Zob.: J. Getka, Polskojęzyczna oferta bazylianów wileńskich (XVIII wiek), [w:] Między Rusia a Polską. Litwa. Od Wielkiego Księstwa Litewskiego do Republiki Litewskiej, red. J. Grzybowski, J. Kozłowska, Warszawa 2014. 
W izolacji wynikającej z miejsca życia i pracy, osamotnieniu w poszukiwaniach literackich i wzmocnionej wykształceniem i oczytaniem fascynacji rodzimym językiem badacze szukają sposobu na uporanie się z kolejnym problemem, a właściwie splotem problemów: jak zaspokoić [...] wielkie pragnienie, by znaleźć dla Donelaitisa miejsce wśród klasyki literatury światowej ${ }^{64}$, a przy tym satysfakcjonująco nazwać jego dzieło, które na wielu poziomach zaprzeczało konwencji literackiej swoich czasów? A zaprzeczało. Nawet jeśli Donelaitis zaczerpnął ze współczesnych sobie lektur tematykę wiejską, apologię natury, a z przykładów antycznych wzór metrum, to wykorzystał te elementy, by osiągnąć rezultat bardzo odległy od obowiązujących reguł. Zamiast obrazu idyllicznego dał realistyczną wizję egzystencji na wsi pańszczyźnianej. Realizm ten ma jednak ograniczenia, bo autor skupił się na rzetelnym odwzorowaniu sytuacji społecznej, nie zindywidualizował natomiast postaci - na tę ,przypadłośćc poematu zwracali uwage pierwsi interpretatorzy dzieła. Mimo że w utworze pojawia się wielu bohaterów, przemawiają oni w jednej tonacji. Wygłaszają pochwałę prostego, choć trudnego, wiejskiego życia, przedstawianego jako dar od Boga, ale dobitniej krytykują postawy, które dostrzegał zapewne sam Donelaitis jako opiekun parafian: niegospodarność, brak umiaru, lenistwo, pijaństwo, brak solidarności we wspólnocie, zachłanność, zazdrość, brak pokory wobec ustalonego przez Boga porządku rzeczy, a równocześnie nadmierną lękliwość w kontaktach z administracją pruską i rządcami ziemskimi. Równie zdecydowanie wieśniacy, którym autor udzielił głosu, potępiają występny i pasożytniczy styl życia warstwy uprzywilejowanej. Źródłem takich motywów nie była literatura epoki, sięgająca po nie rzadko, na ogół przez pryzmat satyry. Rodziły się z codziennych zmagań kapłana i mieszkańca wsi, nie poety.

${ }^{64}$ A. Gustaitienè, Senoji lietuviu literatūra (XIII-XIX): tyrimai Lietuvoje, [w:] Trumpa lietuviu literatūros istorija, red. D. Kuizinienè, Kaunas 2014, s. 17. 
Ustami włościan wyrażał też Donelaitis te oceny otaczającej go rzeczywistości, które stały się dla komentatorów podstawą do klasyfikowania go jako poety narodowego, a mianowicie dezaprobatę dla wynaradawiania się Litwinów, odstępstwa od tradycji i ulegania obcym wzorcom:

Zmieszali się Litwini z Niemcami pospołu

I uczciwe zwyczaje wnet w niepamięć poszty,

Tak że dziś łapci $w$ domu robionych parobek

Nie chce nosić i nie w smak samodziat dziewczynom.

Chłopek w miastowych butach po pańsku odziany, A dziewczęta, niecnoty, w tych spódniczkach modnych

Niczym Szwabki, bez wstydu, paraduja dumnie.

Tak stary swój obyczaj przegrali Litwini ${ }^{65}$.

Repertuar wprowadzanych w wypowiedziach postaci wątków pozwala sądzić, że autora nie interesowały jednostki, przywoływane w tekście niemal wyłącznie po to, by wypowiadały się w imieniu nadrzędnego narratora (dlatego też poszczególni bohaterowie nie otrzymali zróżnicowanych charakterystyk psychologicznych), lecz cała społeczność, jego communitas, wśród której żył i której poświęcał swoją aktywność zawodową oraz, jak wynika z pozostawionych pism, czas osobisty. To ją uczynił bohaterem zbiorowym, próbując uchwycić najważniejsze, w jego mniemaniu, aspekty jej istnienia. Wśród tych aspektów nie znalazła się miłość, temat charakterystyczny dla wyidealizowanych wizerunków wsi tworzonych w tym okresie. Ten brak nie wyczerpuje jeszcze katalogu odstępstw. Polski tłumacz poematu zaliczał do nich również: [...] niespójność tematyczna i narracyjna oraz powtórki i nielogiczności, brak wersów wiążcych $i$ wyraźnych zakończeń niektórych wątków, niejasności, kto jest autorem tej czy innej kwestii.[...] Język miejscami grubiański. Te same , grube” stowa

${ }^{65}$ K. Donelaitis, Pory roku, op.cit., s. 73. 
powtarzaja się aż do znudzenia. Hiperboliczne przesady, mimo że można się w nich doszukać ironii, ida za daleko i raża współczesnego czytelnika. Części poematu nie przystają do siebie, jakby tu i ówdzie brakowało wersu, albo i całego ustepu ${ }^{66}$. Ale w cytowanym wyżej wstępie do polskiego wydania utworu znalazła się też inna opinia tegoż autora przekładu: Litwini stusznie dumni sq ze swojego pierwszego poety, którego nie powstydziłby się żaden z narodów ${ }^{67}$.

Powróćmy zatem do pytania: jak pogodzić rangę klasyka z niefrasobliwością literackiego neofity? Odpowiedź tkwi, być może, nie w rozdzielaniu tych kategorii, ale w potraktowaniu ich jako komplementarnych wobec siebie atrybutów pewnego typu użytkownika ukształtowanego przez konteksty, sprzeczności i niespójności epoki przejściowej, rozpiętej między oralnością a piśmiennością, prowincją i centrum. Gineitis zasugerował ten trop: (...) w „Porach roku” obecna jest pewna warstwa wpływów klasycznych lub późniejszych szkót literackich, lecz fundament poematu zbudowany jest z żywiołu realnego życia, co wymagało od autora zaczerpnięcia $z$ wieloletnich osobistych przeżyć, z bezpośrednich doświadczeńt ${ }^{6}$. Można pójść nim dalej. Studia dały przyszłemu duchownemu-poecie jedynie ogólne przygotowanie do podjęcia wysiłku pisarskiego, do ujmowania jego kapłańskiej i prowincjonalnej codzienności w postaci poetycko uformowanego zapisu, nie stworzyły jednak potrzeby wcielenia się w rolę społeczną pisarza. Stworzyły inną: wykorzystania artystycznej nadorganizacji językowej - ta z licznych definicji literatury pięknej wydaje się tutaj najwłaściwsza - do uporządkowania doświadczenia społecznego organicznej wspólnoty mniejszości narodowej na przykładzie grupy z własnego otoczenia. Donelaitis, mający do czynienia z kulturą przede wszystkim wypowiadaną, nie zapisywaną, pokusił

\footnotetext{
${ }^{66}$ Z. Ławrynowicz, Życie Krystyna Donelajtisa, [w:] K. Donelaitis, Pory roku, op.cit., s. XL.

${ }^{67}$ Ibid.

${ }^{68}$ L. Gineitis, Ivadas, [w:] K. Donelaitis, Raštai, op.cit., s. 10.
} 
się o skonstruowanie jej uniwersalnego modelu, obejmującego jej cykl i rytm działania, właściwy jej język, typy zachowań, postawę wobec tradycji i relacje $\mathrm{z}$,innością".

Był to jednak model daleki od abstrakcyjnej kreacji literackiej, nie w pełni realizujący podsuwaną przez pismo możliwość tworzenia świata na kartce papieru. Prowincjonalny pastor stworzył model adekwatny do jego sytuacji egzystencjalnej; zawarł w nim kronikarskie pragnienie do usystematyzowania życia wspólnoty według kryterium wiejskiego odczuwania czasu, na poły naturalnego, na poły liturgicznego oraz według katalogu gospodarskich powinności, uchybień i trudów. Faktograficzność kroniki zastąpił drobiazgowością w opisie detali składających się na chłopską codzienność, a więc stroju, posiłków, przedmiotów, praktyk i obyczajów. Ławrynowicz nazywa ten opis, za badaczami litewskimi, ,encyklopedią życia litewskiego chłopa" "69, a Gineitis pisze o „etnograficznym kolorycie"70, ale określenia te można odnosić raczej do hojnie zaprezentowanego w poemacie materiału niż do metody. Przez nagromadzenie szczegółów, epizodów i anegdot bliżej Porom roku do mozaikowości sylw szlacheckich z tego okresu. A poszczególne elementy łączy w całość dominujący w utworze moralizatorski ton surowego kaznodziei, chętnie przypominającego słuchaczom/czytelnikom: Wszystkim Bóg miłosierny daje co im trzeba ${ }^{71}$. Gdy zatem badacz litewski akcentuje, że (...) kwestia oryginalności twórczości Donelaitisa była i pozostaje jedna z najbardziej niejasnych i spornych ${ }^{72}$, wolno podsumować inną niż najpopularniejsze $\mathrm{z}$ dotychczasowych, interpretację: wykształcony pastor, którego więź ze środowiskiem akademickim znacznie osłabła, dzielący swą aktywność między wymagające normatywnych form

${ }^{69}$ Z. Ławrynowicz, Życie Krystyna Donelajtisa, [w:] K. Donelaitis, Pory roku, op.cit., s. XXXIX.

${ }^{70}$ L. Gineitis, Kristijonas Donelaitis...,op.cit., s. 252.

${ }^{71}$ K. Donelaitis, Pory roku, op.cit., s. 17.

${ }^{72}$ L. Gineitis, Kristijonas Donelaitis ...,op.cit., s. 294. 
pisanych księgi parafialne a nauczanie wygłaszane do wiernych, dokonał przekładu doświadczenia wspólnoty, obecnego w mowie, na odmienny sposób istnienia języka, na tekst, nie zdając sobie sprawy ze wszystkich konsekwencji przeniesienia homeostatycznej treści do utrwalającego wiedzę i usuwającego kontekst medium. Jedną z istotnych funkcji tego tekstu było „Zwrócenie” tego doświadczenia jego uczestnikom, w zmienionej już, zracjonalizowanej, wyabstrahowanej postaci. W 1818 roku Rėza opatrzył swoje wydanie pieśni Donelaitisa podtytułem „epos wiejski” („landliches Epos”), proponując pierwszą nazwę tego nieschematycznego gatunku. Dzisiaj uprawnione wydaje się nazwanie utworu, by posłużyć się kategorią Goody’ego ${ }^{73}$, „poematem lektooralnym".

Gdy osiemdziesiąt lat po prawdopodobnym powstaniu, a niespełna cztery dekady po wydaniu Pór roku Antanas Baranauskas tworzył swój poemat, kontekst i pisania, i odczytania dzieła był już zdecydowanie odmienny. Co w pierwszej chwili może zaskakiwać, ponieważ społeczeństwo Litwy jako obszaru wyodrębnianego czy to według kryteriów filologiczno-etnicznych, czy też jako część upadłej Rzeczypospolitej, nie doświadczyło w tym czasie rewolucyjnych przemian strukturalnych. Rozbiory unicestwiły byt polityczny, ale nie kulturowy, nie zmieniły też zasadniczo, przynajmniej nie od razu, typu zależności społecznych. W I połowie XIX wieku nie uległo radykalnemu przeformułowaniu pojmowanie kategorii narodu: pojęcie „Litwin” nie wyemancypowało się jeszcze w sensie etnicznym, kulturowym i językowym. Na pewno nie z polskiego punktu widzenia, skoro sto lat później polski autor opisujący reakcje Litwinów na rozbiory i pierwsze sygnały oporu konkludował bez wątpliwości: Poczuła rychło te prądy i nurty najbardziej zdeptana i zgnębiona Litwa. Wewnętrzna dynamika tej twardej czesści narodu, majacego w swej innerwacji psychicznej

\footnotetext{
${ }^{73}$ Chodzi, rzecz jasna, o samo pojęcie lektooralności, zob.: J. Goody, Mit, rytuat i oralność, przeł. O. Kaczmarek, Warszawa 2012, rozdz. Pismo a pamięć ustna. Znaczenie ,,lektooralności”, s. 227-237.
} 
zaszczepione pierwiastki poczucia prawa $i$ wiary w zwycięstwo sprawiedliwości dziejowej; wciąż trwająca w ustroju życia zbiorowego $i$ indywidualnego więź z Korona, jako podstawa sity mocarstwowej złączonych na wieki narodów - musiały zwyciężyć chwilowe oszołomienie myśli politycznej, w rodzaju twierdzenia Czackiego, że Polska jest wymazana z liczby narodów ${ }^{74}$. Przekonanie o ciągłości i trwałości więzi obejmowało zresztą najważniejsze instytucjonalne i znormatywizowane aspekty życia terytorium pod zaborem rosyjskim: Proces cywilny litewsk $i^{75} \mathrm{z} 1826$ roku, podręcznik dla studentów i absolwentów prawa Uniwersytetu Wileńskiego, ważny, bo obejmujący zmiany zapisów prawnych wynikłe z innej przynależności administracyjnej ziem zabranych ${ }^{76}$, różnicę między byłą Koroną a byłym Wielkim Księstwem przedstawiał jedynie jako proceduralną, mimo że odnosił się również do rozstrzygania w sprawach lokalnych. Objawów przekształceń, które mogły spowodować zmianę statusu, umiejscowienia w kontekstach i stylów odbioru publikacji w języku litewskim trzeba szukać nie na powierzchni życia społecznego, lecz głębiej, w przesunięciach we wzorach myślenia jednostek, odosobnionych inicjatywach, wpływach pośrednich i ogniskach wyraźnie widocznych dopiero z perspektywy czasu.

Liudvikas Adomas Jucevičius (Ludwik Adam Jucewicz), podpisujący swoje prace jako Ludwik z Pokiewia, w przedmowie do dzieła, które zapewniło mu później miano „pierwszego litewskiego etnografa", odnotował: (...) piszacy dziś historyję nie powinien przestawać na samych źródłach pisanych, na samych jałowych zapiskach i kronikach, potrzebajeszcze koniecznie zasiegać wiadomości z podań

\footnotetext{
${ }^{74}$ Dr A. Miller, Pierwsza Porozbiorowa Konspiracja Litewska. Spisek ks. Ciecierskiego, przeora Dominikanów Wileńskich (1796-1797). Studium historyczne, Kraków 1936, s.6.

${ }^{75}$ Zob.: A. Korowicki, Proces cywilny litewski, Wilno 1826.

76 Nieformalne, upowszechnione przez Maurycego Mochnackiego określenie większości terytoriów dawnego Wielkiego Księstwa Litewskiego, po rozbiorach włączonych bezpośrednio do Rosji.
} 
miejscowych - z podań ludu. One mu nie jeden ważny wypadek wyjaśnia, nie jedne prawdę zostawiona dotą samemu gminowi, odkryja, ze stanem moralnego ukształcenia, i pojęciami narodu zaznajomia ${ }^{77}$. Jucevičius, postulując nowe zadania dla badaczy dziejów i obyczaju Litwy i wskazując najważniejszy kierunek poszukiwania źródeł w pamięci ludu, nie reprezentował generacji czy nawet skonsolidowanej wokół przedstawionych idei grupy, ale nie był w propagowaniu wzmożonego wysiłku w celu wydobywania i ogłaszania od wieków nietkniętych skarbów narodowej historii ${ }^{78}$ osamotniony.

W latach 1835-1841 ukazały się w 9 tomach Dzieje starożytne narodu litewskiego Teodora Narbutta, praca imponująca zarówno rozmiarami, jak i fantastycznością wywodów i dowodów, pod wieloma względami pozostająca w całkowitej sprzeczności z metodologicznymi wskazówkami Jucevičiusa ${ }^{79}$, choć on sam w cytowanej przedmowie Narbutta wychwalał. Cztery lata później Simonas Daukantas wydał w Sankt Petersburgu najbardziej potem cenione z jego dzieł historycznych i w największym stopniu poświęcone dziejom kultury: Būdas senovés lietuviu, kalnènu ir žemaičiu. Była to publikacja szczególna, bo jedyna wśród druków historiograficznych, która ukazała się po litewsku. W tym czasie czytelnicy mieli już możność poznać szkice historyczne Dionizasa Poški i kolejną gramatykę litewską, wydaną na podstawie anonimowego dziełka z XVIII wieku, przygotowaną do druku i opatrzoną komentarzem przez Simanasa Stanevičiusa. Do tego filologa, zbieracza i wydawcy pieśni należała przez czas jakiś biblioteka Jurgisa Pliaterisa, czy po polsku: Jerzego Konstantego hrabiego Platera, zmarłego w 1836 roku, licząca ponad 3000 woluminów, w większości związanych z tematyką litewską.

\footnotetext{
${ }^{77}$ L. Jucewicz, Litwa pod względem starożytnych zabytków, obyczajów i zwyczajów skreślona przez Ludwika z Pokiewia, Wilno 1846, s. II-III.

${ }^{78}$ Ibid. s. IV.

${ }^{79}$, ,...) na szali zimnej rozwagi i krytyki, wszystko roztrząsnąć, przeważyć, i z tej gmatwaniny coś pewnego utworzyć”. Ibid. s. II.
} 
Nazwisk wymienić można jeszcze co najmniej kilkanaście, bo pisanie tekstów historycznych i filologicznych, głównie po polsku lub po łacinie, a także uprawianie poezji - w tym przypadku spisywanej częściej już po litewsku, ale też z tego powodu dłużej, czasami dziesięciolecia, czekającej na publikację - było nie tylko popularne, ale i pożądane. Małgorzata Litwinowicz-Droździel tak wyjaśnia to nowe napisanie dziejów w różnych ujęciach i z perspektywy różnych dziedzin humanistyki: Zmienne jest miejsce społeczne owego opowiadacza, a przede wszystkim zmienia sie jego świadomość własnej roli, wyobrażenie o tym, czym sa dzieje i co naprawdę godne jest opowiadania. Ulega wreszcie zmianie wyobrażenie czasu i kierunku, w którym dzieje zmierzają. Historia romantyków staje się teofanią, mit wiecznego powrotu zastapiony zostaje przez historię teleologiczna ${ }^{80}$. Ta powiązana tylko osobistymi więziami formacja historyków specjalistów i amatorów, poetów i kolekcjonerów zrodziła się, a w każdym razie rozkwitła z impulsu, jakim był przełom romantyczny w kulturze. Ale miała jeszcze jedną wspólną płaszczyznę - większość z należących do niej twórców rekrutowała się z absolwentów Uniwersytetu Wileńskiego.

Przełom XVIII i XIX wieku był burzliwym okresem w dziejach wileńskiej uczelni. Utworzona w 1773 roku Komisja Edukacji Narodowej, prawzór instytucji zajmujących się strukturą systemu oświatowego, przejęła spuściznę materialną Towarzystwa Jezusowego i jezuicka Akademia Wileńska została przekształcona wkrótce potem w Szkołę Główną Litewską, tym razem już placówkę świecką. Komisja była początkowo niezadowolona z poziomu nauczania, jednak gdy rektorem uczelni został w 1780 roku Marcin Poczobut, zdaniem Marcelego Kosmana, wybitny uczony, pasjonat, świetny organizator ${ }^{81}$, szkoła zaczęła się szybko rozwijać, konkurując coraz skuteczniej

\footnotetext{
${ }^{80}$ M. Litwinowicz-Droździel, O starożytnościach litewskich. Mitologizacja historii w XIX-wiecznym piśmiennictwie byłego Wielkiego Księstwa Litewskiego, Kraków 2008, s. 14.

${ }^{81}$ M. Kosman, Uniwersytet Wileński 1579-1979, Wrocław 1981, s. 32.
} 
z ośrodkiem krakowskim. Nim jednak reorganizacja dokonała się w pełni, nastąpił II i III rozbiór Polski. W 1797 roku uczelnia stała się Szkołą Główną Wileńską, i choć było to już po śmierci carycy Katarzyny II, wyjątkowo nieprzychylnej tej placówce, szkoła trwała niejako w zawieszeniu - nie zapadły ostateczne decyzje co do jej przyszłości, nie było też wiadomo, kiedy zapadną, bo zainteresowanie władz carskich sprawa uniwersytetów było niewielkie ${ }^{82}$, a generał gubernator Litwy, książę Nikołaj Repnin, nie podejmował w tej kwestii żadnych inicjatyw własnych.

Dopiero reformy cara Aleksandra I, znacznie bardziej świadomego znaczenia nowoczesnego nauczania na poziomie akademickim i podpisany przez niego w kwietniu 1803 roku Akt potwierdzenia ${ }^{83}$ otworzyły nowy etap w dziejach uczelni, zwanej teraz Imperatorskim Uniwersytetem Wileńskim. Uniwersytet stał się częścią wileńskiego okręgu szkolnego, którym zarządzał w funkcji kuratora książę Adam Jerzy Czartoryski, uchodzący za wielkiego miłośnika nauk. Związane z nim nadzieje wileńskich profesorów i studentów okazały się słuszne - Uniwersytet szybko zyskał rangę najważniejszej uczelni nie tylko na ziemiach byłej Rzeczypospolitej, ale i w Rosji. Mimo to zmiany, które zaszły na uczelni, oceniane są przez badaczy z ambiwalencją. Marceli Kosman pisał: Wilno (...) położyło nacisk na zatrudnianie - zazwyczaj przez konkursy - uczonych zagranicznych $w$ wolnych katedrach. Miało to swoje dobre i złe strony; dobre, bo szybko zyskiwano fachowców, złe, gdyż z reguły byli to ludzie indyferentni wobec nowego kraju w najlepszym przypadku, w najgorszym zaś idacy ręka $w$ rękę z zaborca $w$ jego dażeniach wynaradawiajacych ${ }^{84}$. Libertas Klimka podkreślał ogromny rozwój nauk ścisłych na uczelni, z którym wiązało się podniesienie poziomu całości nauczania i ułatwienia

82 J. Kamińska, Universitas Vilnensis 1793-1803. Od Szkoły Głównej Wielkiego Księstwa Litewskiego do Imperatorskiego Uniwersytetu Wileńskiego, Warszawa 2012, s. 10.

${ }^{83}$ Zob.: Ibid., s. 108; M. Kosman, Uniwersytet..., op.cit., s. 38.

${ }^{84}$ M. Kosman, Uniwersytet..., op.cit., s. 41. 
w organizowaniu wyjazdów stypendystów Uniwersytetu na renomowane uczelnie zagraniczne, z drugiej strony zwracał jednak uwagę, że administracja carska przyglądała się szkole cały czas z niepokojem, słusznie dopatrując się w niej zarzewia ruchów niepodległościowych ${ }^{85}$. Najbardziej interesują nas jednak rozważania Juozasa Girdzijauskasa, który podsumował wkład Uniwersytetu w rozwój kultury litewskiej w tym okresie. Poświęca on mianowicie wiele miejsca na wskazanie, że inicjatywy o charakterze lituanistycznym były przez grono wykładowców i administratorów uczelni postrzegane jako szkodliwe lub nieistotne, dlatego większości takich przedsięwzięć, jak wydawanie książek w języku litewskim czy uruchomienie katedry filologii litewskiej, nie udało się ostatecznie zrealizować. Dodaje jednak: Niezależnie od nieprzychylności i wszelkich trudności, wpływ Uniwersytetu Wileńskiego na rozwój kultury litewskiej był znaczacy i owocny. Przede wszystkim dlatego, że oficjalny i gtęboko zakorzeniony pogląd na naród litewski i jego kulturę nie pokrywat się z poglądami poszczególnych wykładowców i profesorów. Z różnych, głównie naukowych względów, na Uniwersytecie interesowano się lituanistyka, zachęcano do tworzenia prac i prowadzenia badań $w$ tej dziedzinie $e^{86}$.

Można by więc rzec, że to Uniwersytet Wileński wydał profesjonalnie przygotowaną publiczność literacką, która oceniała i interpretowała dzieło Baranauskasa, korzystając już z całego „typograficznego zaplecza umysłowego”, zdobytego w trakcie studiów i pracy na uczelni. Ale nie był on jedyną kuźnią litewskiej inteligencji połowy XIX wieku. Swój udział w krzewieniu wiedzy o kulturze litewskiej i języku, a także w upowszechnianiu publikacji zawierających teksty litewskie, a co za tym idzie, w zachęcaniu do ich tworzenia i czytania, miał również Uniwersytet Królewiecki, od dawna

${ }^{85}$ L. Klimka, Mokslo raida Lietuvoje XVI-XIX a.: europinis kontekstas, [w:] Lituanistika šiuolaikiniame pasaulyje, T. VII-VIII, red. J. Girdzijauskas, Vilnius 2004, s. 79-81.

${ }^{86} \mathrm{~J}$. Girdzijauskas, Kultūros židiniai, [w:] Lietuviu literatūros istorija XIX amžius, red. J. Girdzijauskas, Vilnius 2001, s. 32. 
przychylny sprawie litewskiej. Od początków XVIII stulecia działało na uczelni seminarium języka litewskiego, był on zresztą wykładany już wcześniej. Uniwersytet dysponował prawdopodobnie najbogatszą w owym czasie biblioteką lituanistyczną. W drugiej dekadzie XIX wieku Liudvikas Rėza, profesor i prorektor w murach Albertyny, wydawca pieśni litewskich i Donelaitisa, był uważany za największego żyjącego lituanistę, niekwestionowany autorytet $\mathrm{w}$ tej dziedzinie ${ }^{87}$. Grono lituanistyczne Uniwersytetu Królewieckiego współtworzyli też Peter Bohlen, Fridrichas Kuršaitis i Georg Nesselmann, wybitni językoznawcy, którzy opracowali naukowe podstawy współczesnej filologii litewskiej - w porównaniu z ich dokonaniami osiągnięcia litewskie w tej dziedzinie na terytorium objętym zaborem rosyjskim miały ,amatorski charakter" ${ }^{\prime 8}$.

A jednak, mimo tak wysokiego poziomu badań nad językiem litewskim, a może właśnie z tego powodu, Uniwersytet Królewiecki nie stał się ostoją litewskiego ruchu narodowego. Język litewski pozostał tu przez cały wiek XIX przedmiotem zainteresowania wyłącznie naukowego, nie pożywką idei o wymiarze społecznym czy tożsamościowym. Litewscy absolwenci uczelni mieli w przyszłości pomóc w organizacji ruchu przemytników książek, ograniczali jednak swój udział (poza grupą nielicznych aktywnych przemytników) do działalności wydawniczej po pruskiej stronie granicy. Ale to zjawisko wymaga osobnego omówienia w innym tekście ${ }^{89}$ - powróćmy tymczasem do Baranauskasa i przytoczonej wcześniej legendy.

Niezależnie od tego, czy opowieść księdza Jakštasa oparta była na zdarzeniach prawdziwych, czy służyła jedynie mitologizacji najsłynniejszego utworu przyszłego biskupa sejneńskiego, zawiera bardzo cenną wskazówkę dla badacza kultury litewskiej połowy XIX wieku. Antanas Baranauskas, w odróżnieniu od Donelaitisa, nie

\footnotetext{
${ }^{87}$ Ibid., s. 35.

${ }^{88}$ Ibid., s. 36.

${ }^{89}$ Zob. przypis 16 .
} 
tworzył swego poematu w odizolowaniu, w piśmienniczej próżni, bez dostępu do bibliotek, książek innych niż podstawowa literatura liturgiczna, bez kontaktów z ludźmi pióra i w oddaleniu od ośrodków życia intelektualnego. Wprost przeciwnie. To prawda, że piśmiennictwo litewskie nie wydało w tym czasie innych pisarzy na miarę Baranauskasa, że literatura litewska mierzona dorobkiem pokoleń miała się dopiero pojawić. A mimo to wyobraźnia artystyczna Baranauskasa, jego postrzeganie literatury i motywacje pisarskie formowały się w środowisku, które można nazwać bardzo zalążkową jeszcze, ale rozwijającą się dość dynamicznie litewską reprezentacją Republique des Lettres ${ }^{90}$.

By obronić to twierdzenie, może warto przypomnieć kilka faktów biograficznych. W 1851 roku, jako nastolatek, Baranauskas rozpoczął naukę w szkole kancelistów w Rumszyszkach funkcjonującej pod patronatem rosyjskiej Izby Skarbowej. Tam zaczął pisać wiersze, dziennik osobisty i listy do rodziców - w tym okresie jeszcze wyłącznie po polsku. Stylistyka pierwszych prób literackich i wątki powracające w zapiskach prywatnych pozwalają przypuszczać, że młodzieniec miał dostęp do książek, i to w dosyć szerokim wyborze. Egidijus Aleksandravičius sugeruje, że czytywał nawet Pieśni Osjana i dzieła Byrona ${ }^{91}$, niewątpliwie natomiast poznawał twórczość romantyków polskich, zwłaszcza Słowackiego, sądząc po licznych zapożyczeniach we wczesnych próbkach lirycznych. Lektura i zapis były częścią jego codzienności. Był to sposób na zdobywanie wiedzy, ale w większym jeszcze stopniu na swoisty trening umysłu. Badacz litewski pisze: Doświadczenia z Rumszyszek rzeczywiście nie poszły na marne. Towarzyszacy Baranauskasowi przez całe życie nawyk samodzielnej nauki z pewnościa pochodził z tamtego okresu ${ }^{92}$.

${ }^{90}$ Zob. K. Pomian, Europa i jej narody, przeł. M. Szpakowska, Warszawa 1992, s. 78 i dalsze.

${ }^{91}$ E. Aleksandravičius, Antanas Baranauskas. Szlak wieszcza, op.cit., s. 51.

${ }^{92}$ Ibid., s. 52. 
W 1855 roku, już jako pisarz gminny z pewnym, raczej negatywnym doświadczeniem w tej profesji, rozmyślający coraz poważniej o wstąpieniu do stanu duchownego, Baranauskas przeżył iluminację: poznał Karolinę Proniewską, szlachciankę i poetkę, starszą od niego o siedem lat. O szczegółach tej znajomości historycy literatury debatują od lat, pozostawmy więc wątek osobisty dociekliwym biografom. Ważne jest tutaj co innego. Ponownie trzeba oddać głos litewskiemu uczonemu: (...) Karolina Proniewska była osoba, która podtrzymywała nie tylko poetyckie aspiracje Baranauskasa, ale i słabnace uczucia religijne. Nie ma wątpliwości, że dla samego Baranauskasa przekroczenie progu salonu szlacheckiego było niczym dar boży. O tym marzyt w kancelarii, to wyobrażat sobie, jadac turkoczacym chłopskim wozem czy kroczą przez błotniste żmudzkie miasteczka. W końcu poznat takie towarzystwo, za którym tęsknit, gdy czytat ksiązki. Takie środowisko to byty wzniosłe uczucia, intensywne życie umysłowe, subtelny gust ${ }^{93}$.

Dzięki przyjaźni z rodziną Proniewskich poeta dołączył do grona słuchaczy seminarium duchownego w Worniach, gdzie kontakt z literaturą, również tą najnowszą, stanowił istotny składnik zdobywanego wykształcenia. Gdy więc kilka lat potem, kończąc już ten etap edukacji i stając u progu kariery duchownej, Baranauskas pisał Borek oniksztyński, pisał go jako praktyk piśmienności, wobec literatury - nawet jeśli bezpośrednim impulsem nie było zdarzenie utrwalone w anegdocie - i dla literatury. Tak też odczytywali utwór współcześni: jako manifest idei patriotycznej, estetycznej, w pewnym stopniu pokoleniowej, w pewnym - politycznej, bo mimo że nie ma w poemacie wyrażonych wprost aluzji politycznych, cenzura i tak miała zastrzeżenia do podzielonego na dwie części obszernego tekstu poetyckiego, przedstawionego do zatwierdzenia na łamach kalendarzy L. Ivinskisa w 1860 i 1861 roku$^{94}$. Wcześniej zgody na druk udzielił młodemu duchownemu biskup Valančius, z którego in-

${ }^{93}$ Ibid. s. 65.

${ }^{94}$ Zob. przypis 20 . 
spiracji miał wkrótce wyrosnąć ruch przemytników książek. Poezje te miały żywo rozbrzmiewać przez długie lata. Algis Kalèda pisał, że na nich wychowywało się pokolenie, które miało wprowadzić Litwę W niepodległość ${ }^{95}$.

Być może świadomość znaczenia literatury, funkcji słowa literackiego, utraty kontroli nad słowem zapisanym, wydrukowanym i powierzonym czytelnikom skłoniły Baranauskasa do rozstania z tą formą komunikacji, wszak Borek..., utwór najdoskonalszy, był zarazem jednym z ostatnich. Przed ukończeniem 30. roku życia Baranauskas zrezygnował z kontynuowania kariery literackiej. Był to czas powstania styczniowego - czy duchowny, przebywający daleko od objętych walkami ziem rodzinnych, domyślał się związku między zadaniem pisarza i powinnością patrioty? Nie znamy dokładnych przyczyn decyzji księdza Baranauskasa. Pewne jest jednak, że to właśnie pierwsza generacja jego czytelników miała podjąć po upadku powstania styczniowego i wprowadzeniu zakazu druku aktywną walkę o niezbywalny instrument zachowania własnej tożsamości, litewską książkę drukowaną.

\section{Wybrana bibliografia:}

1. Aleksandravičius E., Antanas Baranauskas. Szlak wieszcza, przeł. J. Rogoża, T. Błaszczak, Sejny 2014.

2. Aleksandravičius E., Kulakauskas A., Pod władzą carów. Litwa w XIX wieku, przeł. B. Kalęba, Kraków 2003.

3. Baranauskas A., Anykščiu šilelis, red. J. Jablonskis, Vilnius 1905.

4. Baranauskas A. (Baranowski A.), Anykščiu šilelis (Borek oniksztyński), przekład poetycki J.J. Rojek, przekład filologiczny J. Wajna, wstęp M. Jackiewicz, Olsztyn-Białystok 1987 (wydanie dwujęzyczne).

5. Baranauskas A., O mowie ludu żmudzkiego i litewskiego, [w:] „Litwa” 1112/1913.

6. Baranowski A., Anykszczu szilelys, [w:] A. Weber, Ostlitauische Texte, Weimar 1882.

${ }^{95}$ A. Kaleda, Dzieje literatury litewskiej, T. 2, 1918-2000, Warszawa 2003, s. 7-8. 
7. Barthes R., La Bruyère: od mitu do literatury, [w:] J. de La Bruyère, Charaktery, przeł. A. Tatarkiewicz, Warszawa 1965.

8. Basanavičius J., Prakalbosvieton, [w:] Gabija. Rinktine knyga, paaukota lietuvos dainiaus vyskupo Antano Baranaucko atminimui, knyga sutaise ir spaudai prirengè Juozapas Gerbačauskis, Kraków 1907.

9. Biržiška M., Iš mūsų kultūros ir literatūros istorijos, T. 1, Kaunas 1931.

10. Biržiška V., Aleksandrynas. Senujų lietuvių rašytojų, rašiusiu prieš 1865 m., biografijos, bibliografijos ir biobibliografijos, T. I-III, Vilnius 1990.

11. Biržiška V., Nežinomas 1769 m. Donelaičio spaudinys, [w:] Varpai. Literatūros almanachas, Šauliai 1944.

12. Brazaitis J., Buros kulturos poetas, [w:] Egzodo Donelaitis: Lietuvių išeiviu tekstai apie Kristijona Donelaiti, Vilnius 2001.

13. Donelajtis K./Donelaitis K., Pory roku/Metai, tłum. Z. Ławrynowicz, OlsztynBiałystok 1982, (wydanie dwujęzyczne).

14. Donelaitis K., Raštai, red. K. Korsakas, Vilnius 1977.

15. Donelaitis K, Raštai. Pagal Rèzos, Šleicherio ir Neselmano sutaisé J. Šlapelis, Vilnius 1909.

16. Getka J., Polskojęzyczna oferta bazylianów wileńskich (XVIII wiek), [w:] Między Rusią a Polską. Litwa. Od Wielkiego Księstwa Litewskiego do Republiki Litewskiej, red. J. Grzybowski, J. Kozłowska, Warszawa 2014.

17. Gineitis L., Kristijonas Donelaitis ir jo epocha, Vilnius 1964.

18. Gineitis L., Prūsiškas patriotizmas ir lietuvių literatūra, Vilnius 1995.

19. Godlewski G., Stowo - pismo - sztuka stowa. Perspektywy antropologiczne, Warszawa 2008.

20. Goody J., Mit, rytuat i oralność, przeł. O. Kaczmarek, Warszawa 2012.

21. Goody J., Watt I., Nastepstwa piśmienności, przeł. J. Jaworska, [w:] Communicare. Almanach antropologiczny. T. II: oralność/piśmienność, Warszawa 2007.

22. Grinius J., Veidai ir problemos lietuviu literatūroje, Roma 1973.

23. Gustaitienè A., Senoji lietuviu literatūra (XIII-XIX): tyrimai Lietuvoje, [w:] Trumpa lietuvių literatūros istorija, red. D. Kuizinienė, Kaunas 2014.

24. Jackiewicz M., Dzieje literatury litewskiej. T. 1: do 1917 roku, Warszawa 2003.

25. Jakštas A., Kas ikvepè A. Baronui „Anykščiu šilelì?, [w:] Gabija. Rinktiné knyga, paaukota lietuvos dainiaus vyskupo Antano Baranaucko atminimui, knyga sutaisè ir spaudai prirengè Juozapas Gerbačauskis, Kraków 1907.

26. Jovaišas A., Kristijonas Donelaitis: gyvenimas ir kūryba, Kaunas 1992. 
27. [Jucewicz, L.] Litwa pod względem starożytnych zabytków, obyczajów i zwyczajów skreślona przez Ludwika z Pokiewia, Wilno 1846.

28. Kalèda A., Dzieje literatury litewskiej. T. 2: 1918-20, Warszawa 2003.

29. Kalendorius ukiszkasis nuog użgimima Wieszpaties 1861 metu paprastunju, turenćziun 365 dienas. Paraśzitas par Ł. Iwiński, Vilniuje 1860.

30. Kamińska J., Universitas Vilnensis 1793-1803. Od Szkoły Głównej Wielkiego Księstwa Litewskiego do Imperatorskiego Uniwersytetu Wileńskiego, Warszawa 2012.

31. Klimka L., Mokslo raida Lietuvoje XVI-XIX a.: europinis kontekstas, [w:] Lituanistyka šiuolaikiniame pasaulyje, T. VII-VIII, red. J. Girdzijauskas, Vilnius 2004.

32. Kolberg O., Dzieła wszystkie, T. 53. Litwa, Wrocław-Poznań 1966.

33. Kosman M., Uniwersytet Wileński 1579-1979, Wrocław 1981.

34. Lietuviu literatūros istorija XIX amžius, red. J. Girdzijauskas, Vilnius 2001.

35. Litwinowicz-Droździel M., O starożytnościach litewskich. Mitologizacja historii w XIX-wiecznym piśmiennictwie byłego Wielkiego Księstwa Litewskiego, Kraków 2008.

36. Mikšytė R., Antanas Baranauskas, Vilnius 1993.

37. Miller A., Pierwsza Porozbiorowa Konspiracja Litewska. Spisek ks. Ciecierskiego, przeora Dominikanów Wileńskich (1796-1797). Studium historyczne, Kraków 1936.

38. Naujokaitis P., Lietuvių literatūros istorija. T. I: Nuo Mažvydo iki Maironio, Brooklynas 1973.

39. Niemojewski M., Knygnešiai, czyli o narodzinach litewskiej inteligencji, [w:] Sploty kultury, red. N. Dołowy-Rybińska i inni, Warszawa 2010.

40. Niemojewski M., Litewskie kalendarze $w$ drugiej połowie XIX wieku: inicjacje wspólnoty praktyków stowa drukowanego, [w:] Antropologia praktyk językowych, red. G. Godlewski, A. Karpowicz, Warszawa 2016.

41. Pomian K., Europa i jej narody, przeł. M. Szpakowska, Warszawa 1992.

42. Rhesa D.L.J., Vorbericht, [w:] Das Jahr in vier Gesängen : ein ländliches Epos, Konigsberg 1818.

43. Šliupas J., Lietuviszkiejie rasztai ir rasztininkai, Tilžè 1890.

44. Venclova T., Mit o początku, przeł. R. Śliwowski, [w:] tegoż, Kształty nadziei, Warszawa 1985. 